\title{
Cerrahi Girişim Sürecinde Çocuk Hastaya Yaklaşım
}

\author{
Approach to Pediatric Patients during Surgical Interventions
}

\begin{abstract}
Yazışma Adresi/Address for Correspondence Hemşire Seher Ünver Trakya Üniversitesi Balkan Yerleșkesi, Sağlık Bilimleri Fakültesi, Cerrahi Hastalıkları Hemșireliği Anabilim Dall, Edirne, Türkiye Gsm.: +905055007217 E-posta: seher.unver@hotmail.com

Geliş Tarihi/Received: $X X$ Kabul Tarihi/Accepted: 13.09.2013

(c) Güncel Pediatri Dergisi, Galenos Yayınevi tarafindan basilmıștır.

(c) The Journal of Current Pediatrics, published by Galenos Publishing.
\end{abstract}

\section{ÖZET}

Çocuklarda cerrahi süreç, kendileri ve aileleri için genelde hoş olmayan ve zor deneyimleri içermektedir. Bu süreçteki çocuk, anksiyete ve stresi oldukça yoğun yaşar. Diğer taraftan çocuk hastalar, ameliyat sürecine doğrudan etki eden oldukça karmaşık konuma sahiptir. Çünkü çocuk hastanın bakımı sadece rutin cerrahi bakım prosedürünü ve ameliyathanedeki hasta bakımını içermez. Bunların yanı sıra, çocuk hava yolunu, anatomi ve fizyolojisini, çocuk gelişimini bilmeyi, çocuk ile ailenin bakımını üstlenebilmeyi gerektirir. Bu derleme, cerrahide çocuk hastalara ilişkin göz önünde bulundurulması gereken farklııkları ve ameliyat süresince dikkate alınması gereken bakımları sunmak amacıyla hazırlanmıştır. (Güncel Pediatri 2013; 11: 128-33)

Anahtar kelimeler: Cerrahi, çocuk, perioperatif bakım

\section{SUMMARY}

A child's surgical period usually contains unpleasant and difficult experiences, for the child and the parents. The child in this period experiences greater anxiety and distress. On the other hand, pediatric patients have complex states that directly effects their perioperative care during. Because their perioperative care includes not only the knowledge of general surgical procedure and care of a patient in the operating room. It also includes the specific understanding of a child's airway, anatomy and physiology, the understanding of child development and care of the child and family. This review is prepared to present these differences of the pediatric surgical patients and the care during their perioperative period. (Journal of Current Pediatrics 2013; 11: 128-33)

Key words: Surgery, pediatric, perioperative care

\section{Giriş}

Cerrahinin bir dalı olan çocuk cerrahisi, prematüre yenidoğan adolesan dönemdeki çocuğa kadar geniş bir yaş aralığında hasta grubunu kapsamaktadır. Hastane ortamı, çalışanlar, kullanılan malzemeler ve yapılacak işlemler hastaneye yatan her gruptaki çocuk için birer bilinmezlik durumu olup; çocuğun hastaneye ve tedaviye uyumunu, sağlık çalışanıyla iletişimini ve ileriki hastane deneyimini etkileyebilmektedir. Hastaneye yatmaya ek olarak cerrahi bir girişiminin yapılacak olması, çocuk tarafından daha fazla stresin yaşanmasına neden olmakta; çocuğu hem psikolojik hem de fizyolojik yönden daha fazla etkilemektedir (1-4).

Ameliyatın çocuk üzerinde meydana getirdiği strese neden olan faktörler şunlardır:

- Bedeninde meydana gelen olumsuz değişim, fiziksel bütünlüğünün bozulması ve bunun sonucunda oluşan ağrı ve rahatsızık hissi
- Aileden, güvendiklerinden ve sevdiklerinden ayrılma, alışkın olmadığı ve tanımadığı bireylerin yanında bulunma

- Bilinmezliğin getirdiği korku

- Sinırlamaların olması

- Kontrolün, otonominin ve yeteneklerin kaybı

- Ebeveynlerinin olumsuz davranışları (aşırı koruyuculuk, eleştiri, empati ve çocukta yeterli kontrolü sağlayamamak) $(5,6)$.

Bunların yanı sıra ameliyat olacak çocukların ailelerinin de stresini artıran ve çocuklarına destek olmalarını engelleyen durumlar olabilmektedir. Bunlar;

- Çocuklarının bedensel olarak cerrahi hasara uğrayacak oluşu ve buna bağlı ağrı, yetenek kaybı, organ kaybı ya da ölüm gibi durumlarla karşılaşma olasılığı,

- Ebeveyn rolünde değişim,

- Çocukla kurulacak iletişimde yetersizlik,

- Yoğun bakım ortamı ve 
- Çocukta ameliyat sonrası dönemde; bedensel, davranışsal ya da emosyonel yönden meydana gelen değişimlerdir (5).

Çocuğun ameliyata yeterli hazırlanması, onunla etkili iletişimin kurulması ve gereken duygusal desteğin çocuğa verilmesi; ameliyattan olumlu sonuçların elde edilmesine katkıda bulunacak ve aynı zamanda ailenin de bu hazırlığa katılması ile ailenin kültürü, ameliyata dayanma gücü, önceki deneyimleri konusunda da bilgi edinilmesine yardımcı olacaktır $(1,7,8)$.

Çocuğun ameliyatına karar verilmesi ile başlayan ve ameliyata sonrasına kadar devam eden süreçte çocuk ve aile ile güven ilişkisinin geliştirilmesi, bu sürecin sorunsuz olarak geçirilmesini sağlamaktır (9). Hazırlık süreci içindeki bakım dönemlerine ilişkin yaklaşımlar şu başlıklar altında ele alınabilir:

a) Ameliyat öncesi hazırlık sürecinde yaklaşım

b) Ameliyata alınma ve anestezi indüksiyonu öncesi hazırlık sürecinde yaklaşım

c) Ameliyatın başlaması ve ayılma sürecinde yaklaşım.

\section{Ameliyat Öncesi Hazırlık Sürecinde Yaklaşım}

\section{Cocuklarda Yaklaşım}

Çocuklarda yapılan ameliyatın başarılı olabilmesi, teknik bilgi ve becerinin yanı sıra ameliyat öncesi hazırlık ve bakım gereksinimlerinin karşılanmasına bağlıdır. Ameliyata hazırlıkta çocuklardaki durum, içinde bulundukları gelişimsel dönemlere göre değişiklik gösterir $(7,9,10)$.

Yenidoğanlar ve Süt Çocukları: Bu dönemdeki çocuklar fiziksel ve duygusal her tür intiyaçlarını karşılayan ebeveynlerine ve diğer bakıcılarına karşı güven üzerine bir ilişki kurar. Ameliyat nedeniyle bu bireylerden ayrılmak, tanımadığı, kendilerini sevdiklerinden ayıran, maskeli bireylerin olduğu bir ortama girmek onlar için kritik ve korku verici bir durumdur. Bu nedenle hazırlık aşamalarında çocukların ebeveynleri ya da bakıcıları ile birlikte olmaları sağlanmalıdır. Ameliyathanede karşılaşacağı ekibin üyelerinin, güven verici ses tonu ile çocuğa fırsat buldukça ziyarette bulunmaları, onlara dokunmaları ve güven verici ilişkiyi kurmaları, bu dönemde çocuğun hazırlığında önem taşımaktadır $(9,11,12)$.

Oyun Dönemi ve Okul Öncesi Dönem: Bu dönem, çocukların kendi otoritelerini ve kontrollerini kurdukları, aynı zamanda yaratıcı düşüncelerinin oluşmaya başladığı bir dönemdir. Bu dönemde çocuk büyülü düşüncelere sahiptir ve soyut düşünemez. Ameliyatın kendisine verilen bir ceza olduğunu düşünebilir. Sözel açıklamalar yetersiz kalacağından ameliyatla ilgili açıklamalar oyuncak bebek, ayı veya renkli resimler üzerinde açıklanabilir. Zaman kavramı iyi gelişmediğinden zamanla ilgili açıklamalar ise olaylar üzerinden, fazla detaya girmeden yapılmalıdır. Verilecek açıklayıcı bilgilerde resimlerin ve anlayabilecekleri terimlerin kullanımında fayda vardır. Ameliyathaneyle ilgili açıklamalarda; odanın karanlık olmayacağı ve ameliyathanede yeşil gömlek ve pantolon giymiş, maske ve bone takmış kişilerin olacağı söylenir. Çocuğun bu kişiler ile tanışması sağlanır. Eğer varsa çocukların bebek oyuncaklarına ameliyathane kıyafetleri giydirilebilir. Çocukta somut düşünceler olduğu için ameliyat lambaları, aletler, tansiyon aleti, oksimetre, serum seti, anestezi maskesi ve balonu gösterilebilir. Bu uygulamalar sırasında çocuk, soru sormaya teşvik edilmelidir $(7,9,12,13)$.

Çocukla konuşurken ifadeler çok iyi seçilmeli, çocuğun anlayabileceği dilde ve açık ifadeler kullanılmalı, tehdit edici ifadelerden kaçınılmalıdır. Çünkü çocuklar, gelişimsel yaş dönemlerine göre kullanılan tıbbi terimlere farklı anlamlar yükleyebilir. Örneğin, kesme ifadesi yerine "küçük bir açıklık oluşturmak" ifadesini kullanmak daha doğru olacaktır. Çocukların ölümü sonsuz bir uyku olarak algılamaları ve bu uykudan uyanamayacaklarını düşündükleri için "uyuma" kelimesi çocuk için ürkütücü olabilir. Bu nedenle çocuğa ameliyat bittikten sonra uyanacağı, uyanacağı yerde doktor ve hemşirelerin olacağı, elinde serum takılı olabileceği, sargı ile ameliyatta yapılan açıkığın kapatılmış olacağı belirtilmelidir. Çocuğu avutmak için kaygıyla yalan söylemek, bazı şeyleri anlatmamak ve gizlemek, çocukla kurulması gereken güvene dayalı ilişkiyi bozacaktır $(2,5,9,14)$.

Okul Dönemi: Bu dönemde açıklamalar, oyuncak bebek ya da maket üzerinde gösterilerek yapılabilir. Çocukta kontrol kaybı, beden hasarı ve ölüm korkusu olduğundan, açıklamalar bu özellikleri dikkate alınarak yapılmalıdır. Terapötik oyun yöntemiyle çocuk, hastaneye yatmasının ve ameliyat olmasının nedenini daha iyi anlayabilir ve bunların neden olduğu stresle daha etkili baş etmeyi öğrenebilir. Bu oyun yöntemiyle eğitimler, çocukların bir arada olacağı grup eğitimi halinde de olabilir. Gruplar küçük tutulmalıdır. Çocukların anksiyeteli ya da stresli oluşlarına göre $30 \mathrm{dk}$ ya da daha az süre içinde eğitimler tamamlanmalıdır. Bu eğitimlerde de yine maketler, kuklalar, videolar, slayt gösterileri kullanılabilir $(5,7,9,10)$. Ameliyata gitmeden en az yarım saat önce, oyuncakların ve hikaye kitaplarının bulunduğu oyun odasında birtakım oyunlar ile ameliyata hazırlanan 5-12 yaş arasındaki çocuklarda, anksiyete düzeyinin daha düşük olduğu belirlenmiştir (15). Oyun yöntemi sayesinde verilen eğitimler; çocuğun kendini ifade etmesini kolaylaştırmakta, olumlu baş etme yöntemleri geliştirmesini sağlamakta, ev ile hastane arasında bir bağ kurulmasına katkı sağlamakta, çocuğun otonomi ve yeterlilik duygularını tekrar kazanmasına yardımcı olmaktadır. Bu amaçla tıbbi oyuncaklar (maske, eldiven, bone, ameliyat örtüleri gibi) kullanılabilir. Bunlar çocuğa tıbbi ve cerrahi işlemleri göstermede ve çocuğun duygularını ifade etmesinde yardımcı olur (9).

Adölesanlar: Adölesanlar hızlı bir büyüme süreci içindedir. Bu dönemdeki bireye, ameliyatın estetik 
görünüşünü etkileyeceği, beden imajını bozacağı, kontrol kaybına ve arkadaş grubundan ayrımmasına neden olacağı korkusuna kapıllabilir. Cerrahi girişim ya da hastaneye yatmak, özgürlüklerin kısıtlanmasına da neden olacaktır. Bu aşamada adölesan bireye ve ailesine olası durumları açıklanmalı, fikir sahibi olmaları için fırsat verilmeli ve gereken bireysel kontrolü sağlayabilmekte çocuklarına yardımcı olmaları ebeveynlerine söylenmelidir. Adölesanlarda ameliyatla ilgili bilgi vermeye 1 hafta öncesinden başlanmalıdır. Serviste varsa, ameliyata girecek diğer akranlarıyla tanıştıııması ve grup içine girmeye teşvik edilmesi de yararlı olacaktır. Böylece uygun baş etme davranışları geliştirebilir. Konuşmalardaki gerekli gizlilik hususuna dikkat edilmeli, güven oluşturulmalı ve sorduğu sorular dürüstçe cevaplandırılmalıdır. Kendi izni olmaksızın sağlık çalışanıyla paylaştıklarının yaşamını tehlikeye sokacak bir bilgi olmadığı sürece kimseye aktarımayacağını bilmeli ve bu konuda güven oluşturulmalıdır. Adölesanların yüz ifadelerini, beden dilini değerlendirme becerileri oldukça gelişmiştir ve kısa sürede kendileriyle gerçekten ilgilenip ilgilenilmediğinin farkına varabilirler. $\mathrm{Bu}$ nedenle esas ilgilenilen kişinin kendisi olduğu söz ve davranışlar ile hissettirilmelidir. Korkularıyla, davranışlarıyla, tepkileriyle alay edilmemesi ve olduğu gibi kabul edilmesi önemlidir $(7,10,12,16)$.

\section{Ebeveynlerde Yaklaşım}

Ebeveynler cerrahi işlem öncesi çocukları için endişelenir ve bu endişeye ameliyatın olası komplikasyonları, ameliyat ya da anestezi sırasında çıkabilecek sorunlar ve ameliyathanede görev alan ekibe ilişkin kaygılar da eklenir. Bu endişenin önemli bir nedeni, sağlık sorununa ilişkin duyulan suçluluk duygusu olabilmektedir. Ebeveynler, genetik ya da doğumsal bir anomali yüzünden kendilerini, sonradan oluşan bir sorun için de çocuklarına gereği gibi bakamadıkları düşüncesi ile suçluluk yaşayabilirler $(3,8,14,17)$. Ailenin daha önceki ameliyatlara ilişkin deneyimleri de anksiyeteye neden olabilir. Çocukları daha önceden genel anestezi altında ameliyat olan ailelerin anksiyete düzeylerinin, ilk ameliyat olanlara göre daha yüksek olduğu belirlenmiştir (18). Tüm bu etkenler, ebeveynlerin çocuklarına ameliyat sürecinde yardımcı olmalarına engel olabilmektedir. Bu nedenle ameliyat öncesi dönemde ebeveynler ne kadar iyi hazırlanır ve çocuğun ameliyatı hakkında yeterli bilgiye sahip olursa, çocuğa o kadar çok yardımcı olabilir. Bunu sağlayabilmek için, ebeveynlerin çocuk ile birlikte eğitiminde, hastane ve ameliyathane tanıtımı yapılmalı, bekleme odası, yoğun bakım ve çocuğun ameliyattan sonra yatacağı servis tanıtılmalıdır. Tanıtım, bir saatten uzun sürmemeli, tanıtım sırasında ameliyatın tipi, ameliyat öncesi gerekli olan testler (kan, röntgen), ameliyat öncesi hazırlık, ameliyatın büyüklüğüne göre gerekebilecek kan intiyacı, ameliyat sonrası deneyimler (örn; pansuman, dikiş, hareket kısıtııı̆ı) hakkında bilgi verilmelidir. Soru sorma fırsatı verilmeli ve gelen sorular açık ve doğru bir şekilde yanıtlanmalıdır. Verilen bilgileri anlayıp anlamadıkları ve baş etme becerileri değerlendirilmelidir $(9,14,17)$. Verilen eğitim programlarının, ameliyat olacak çocuk ve ailelerinin ameliyat öncesi ve sonrası kaygı düzeylerini etkileme durumunu belirlemek amacıyla yapılan bir çalışmada, kitapçık ve video ile yapılan eğitimin, ameliyat öncesi ve sonrası anne ve çocuklardaki kaygı düzeyini azalttığı belirlenmiştir. Bununla birlikte, çocuklarda video ile yapılan eğitimin kitapçık ile yapılan eğitimden çok daha etkili olduğu saptanmıştır (19).

Tüm bu hazırlıkların tamamlanmasının ardından ameliyathaneye alınma sürecine geçilmektedir. Servis hemşiresi tarafından yapılan hazırlıkların bildirildiği form doldurulmalı ve ardından çocuğun ameliyathaneye sevki gerçekleştirilmelidir (17).

\section{Çocuğun Ameliyat Odasına Alınması ve Anestezi Öncesi Yaklaşımları}

Çocukların \%65'inden fazlasının, ameliyat öncesi dönemde özellikle de anestezi indüksiyonu sürecinde anksiyete ve korku yaşadığı belirlenmiştir (6). Bu nedenle bu aşamadaki tüm girişimler, çocuğu sakinleştirmek ve güvenini korumak için yapılmalıdır. Ameliyat öncesinde çocuğa ve ailesine sakin bir ortam sunulmalıdır. Bu ortamda oyuncakların ya da sakinleştirici videoların bulunması sağlanabilir. Çizgi film karakterleri, oyunlar, hayal kurmak, çocuğa ailesiyle konuşma fırsatı vermek gibi faaliyetler bu alanda yapılabilecekler arasındadır. Anestezi korkusunu engellemek için ise, ameliyathaneye yapılacak ziyaretlerde anestezistin görsel olarak yaptıkları işlemi anlatmaları, çocuklar için eğlenceli bir uygulama olabilmektedir $(4,5,17,20)$.

Ameliyathaneye sevk aşamasında çocuğun ailesinden bir bireyin (çoğunlukla annenin), anestezi indüksiyonuna kadarki süre içerisinde ameliyathanede bulunmasına izin veren uygulamalar olabilmektedir. Buna izin verilmesindeki amaç; çocukta ayrlık anksiyetesinin yaşanmasını engellemektir. Bu uygulamada; maske yolu ile anestezi uygulandıktan sonra, çocuğun yakını bekleme odasına geri gönderilmektedir. Bu aşamadan sonra çocukta ameliyata ilişkin gerekli hazırıklara geçilmektedir. Yakını ameliyat odasından çıktından sonra, çocuk entübe edilmekte, kalp ve solunum izlemi için gereken monitörizasyon hazırlıkları tamamlanmakta, damar yolu açılmakta ve gerekli olduğu durumlar idrar sondası takılmaktadır $(6,10,21)$. Gauderer ve arkadaşları tarafından yapılan bir çalışmada, çocuk cerrahisinde ameliyat olacak çocuklar ile aileleri ele alınmışıır. On beş yaşın altındaki çocuklarda yapılan bu 
çalışmada, hiçbir çocuğa premedikasyon uygulanmamıştır. Çocukların yakınları, maske ile anestezik gazın verilmesinden öncesine kadar ameliyat odasında kalmış ve çocuklarına yakın bir mesafede bulundurulmuştur. Bu çalışmanın avantajları; çocuklarda psikolojik travmanın azaltıması, daha kolay anestezi indüksiyonunun sağlanması ve ailelerin anksiyetelerinin azaltılması olarak saptanmıştır. Çalışma sonunda çocukların ailelerinden de, bu uygulamaya ilişkin olumlu geri bildirim alınmıştır (22).

Ailelerin ameliyathaneye, anestezi indüksiyonuna kadar alınmadığı ameliyatlarda ise, çocuğa olan yaklaşımın, yaşanacak olan anksiyetenin azaltılmasında önemli bir rolü vardır. Çocukla kurulacak iletişimin 2 önemli özelliği vardır. Birincisi; iletişimde verilen mesajın içeriği, diğeri ise; mesajın iletim șeklidir. Konușma sırasında kişinin ses tonu, konuşma hızı, kelimelere verdiği vurgu, yüz mimiklerini maske nedeniyle göremeyeceği için bunun yerine baş hareketleri, ellerini kullanma şekli ve beden duruşu, çocukla kurulacak iletişimde önemli yere sahiptir (10).

Ayrıca çocukla kurulacak iletişim süresince;

- Çocuğun dile getirdiği duyguları, düşünceleri hiçbir zaman çocukça olarak karşılanmamalı,

- Çocuğun espiri yaptığından ya da şaka yollu konuştuğundan emin olunmadıkça söylediklerine gülümsememeli,

- Çocuğa karşı komik olmaya, onu gülmeye zorlayıcı davranışlardan sakınılmalı ve

- Çocuğa iğnenin acıtmayacağı, verilecek ilacın bir şey yapmayacağı gibi ufak yalanlar söylenmemelidir (10).

Dokuz aya kadar olan bebekler ameliyat masasına alınırken, iletişimin içeriğinden anlamayacak olsalar da, ses tonu, yumuşak dokunuş, her işlemde konuşulması, ses tonunun iyi ayarlaması önemlidir. Bir-üç yaş arasındaki çocuklarda ise anlatılacak hikayeler veya söylenecek şarkılar yararlı olabilir. Çocukların yanında sevdikleri oyuncaklarını ya da önemli sayıp ayrılamadıkları eşyaları var ise bunlar ile ameliyat masasına alınabilir $(9,10)$.

\section{Anestezi İndüksiyonu Sonrası Ameliyatın \\ Başlaması ve Ayılma Aşamasında Yaklaşım}

Yetişkinlerde anestezi indüksiyonunda damar yolu tercih edilmesine rağmen, çocuklarda tercih edilen yol solunum yolu ile anestetik maddenin (halotan, sevofluran gibi) uygulanması şeklindedir. Buradaki esas amaç, damar yolu açılma işleminin çocuğun uyanık ve kendinde olmadığı, anestezi etkisi ile bilincin kaybolduğu aşamada yapılmasıdır. Böylece çocuk için stresli, ürkütücü ve acı verici bir uygulama olan bu işlemin yaratacağı olumsuz etkiden korunmuş olacak ve bunun yaratacağı stresin beraberinde getireceği olumsuz stres tepkileri önlenmiş olacaktır. Solunum yolu ile anestezi uygulamasında, gazın kokusu çocuk tarafından hoş karşılanmayabilir ve maskenin yüzüne doğru yaklaştırıması anksiyeteye neden olabilmektedir. Bunu önlemek için maskenin üzerine aromatik yağ uygulanabilir $(17,23)$.

Anestezi indüksiyonunun ardından ameliyat süresince tüm ekip, bilinci kaybolmuş olan çocuğun bakımına özen göstermeli ve her türlü olumsuz etkiden çocuğu korumalıdır. Anestezinin verilmesinden, gerekli damar yolu açma işleminin ve tüplerin (foley, nazogastrik vs) yerleştirilmesinin ardından, sıra çocuğa pozisyon vermeye gelmektedir. Bu işlemin hedefleri arasında; cerrahi girişim için uygun pozisyonun verilebilmesi, ciltteki gerginliklerin önlenmesi, sinir üzerine basınç oluşmasının önlenmesi, yeterli oksijenlemenin sağlanabilmesi için akciğerlerin yeterli genişleyebilmesinin sağlanması, yeterli dolaşım ve doku perfüzyonunu sağlanması ve yeterli ameliyat alanının görülmesinin sağlanmasına yardımcı olmaktır $(17,20)$.

Ameliyathanede önemli bir diğer konu, güvenliktir. Çocuğun uyanık olduğu dönem içinde gereken güvenlik önlemleri alınmalı, çocuk yalnız bırakılmamalı, zarar görebileceği ve çocuğun uzanabileceği mesafede eşyalar bulundurulmamalıdır. Çocuklardaki kardiyovasküler ve solunum yolu anatomisi iyi bilinmeli, cihazlar buna göre yerleştirilmelidir. Çocuklardaki hava yolu daha öndedir ve bu nedenle endotrakeal entübasyonda baş daha fazla ekstansiyona getirilir. Hava yolu aynı zamanda dar olduğundan, tüpün numarası doğru seçilmelidir (17).

Kan kaybı, ameliyat süresince izlenmelidir. Kanlanan gazlı bezler ve sakşın yolu ile ameliyat bölgesinden uzaklaştıılan drenaj miktarı hesaplanmalı, toplam kan kaybı cerraha ve anestezi uzmanına bildirilmelidir. Çocuğun genel durumu; nabzının durumundan, kapiller dolum hızından ve kan basıncından takip edilmelidir. Uzun süren ve komplike ameliyatlarda ise idrar çıkışı ve santral venöz basınç ölçümü mutlaka yapılmalıdır. Aşırı kayıp durumlarında hekim istemi ile kan nakline başlanmalıdır $(17,24)$.

Yenidoğan ve beş kilonun altındaki çocuklar, düşük beden ağırlıkları nedeniyle ameliyat odasının soğuk ortamından ve soğuk ameliyat masasından daha fazla etkilenecektir. Ameliyathanede sıcaklık kaybı çocuğun ıslak ya da soğuk yüzeylerle teması sonucu olabilmektedir. Bir diğer neden ise, cilt yüzeylerin geniş olması nedeniyle sıcaklık regülasyonunun daha zor olmasıdır. Gelişmesi olası hipotermi durumu, hipoglisemi ve apne gibi ciddi durumların gelişmesine neden olabilir. Gereken önlemler alınmaz ise, kısa süren ameliyatlarda dahi hipotermi gelişebilir. Bunu önlemek amacıyla; ameliyat öncesinde ameliyat odası Isıtılabilir ve ameliyat masasına battaniye serilebilir. Normalde ameliyat odalarının sıcaklığı, yetişkin ameliyatları sırasında $21^{\circ} \mathrm{C}$ iken, yenidoğan ya da özellikle düşük ağırlıklı çocukların ameliyatlarında, oda sıcaklığı $26^{\circ} \mathrm{C}$ olabilmektedir. Çocuk ameliyathane odasına alınmadan en az 10 dakika önce oda sıcaklığı ayarlanmalıdır. Gazıı 
bezlerin sıcak su ile ıslatıması, irrigasyon sıvılarının da ısıtılmış olmasında yarar vardır. Çocuğun ıslak olması da yine üşümesine neden olacaktır. Bu nedenle ameliyat bölgesinin ıslak malzeme ile silinmesinin ardından kurulanması yararlı bir uygulama olacaktır $(17,23,24)$.

Ameliyat süresince ağır malzemelerin çocuğun üzerinde bırakılmamasına dikkat edilmelidir. Ağır malzemelerin çocuğun üzerinde olması sonucu cildin bütünlüğünde bozulma meydana gelebilir (17).

Ameliyat sürecinde kan şekerinin kontrolü de bazı durumlarda yapılmalıdır. Özellikle yenidoğanlarda stres sonucu hipoglisemi gelişme riski oldukça yüksektir. Ameliyat stresine bağlı olarak metabolik intiyacın artması durumuna karşın bunu karşılayacak yeterli glikojen deposuna sahip değildir. Bu nedenle kan şekeri düzeyini desteklemek amacıyla dekstroz solüsyonları kullanılabilmektedir (17).

Çocuklarda cerrahi işlem sonrasında yara kapamada kullanılacak materyal, ameliyata bağlıdır. Yavaş iyileşeceği düşünülen yaralarda, emilmeyen özellikte materyal kullanılabilmektedir. Temiz yaralarda birincil iyileşme tercih edilmektedir. Cerrahi yaranın üzeri SIVı geçirgenlikli yara kapama materyali ile (kollodion) kapatılması, çıkarılmadan önce en fazla 3-6 gün kalmakta ve çocuklarda kullanımı yararlı olmaktadır. Bu sayede yara iyileşmesi için gereken nem sağlanmakta ve yara dış etkenlerden korunmaktadır. Eğer çocuk çok hareketli ise "stapler" kullanılabilmektedir. Bu durumda stapler, 5-7 güne kadar kalmaktadır (17).

Cerrahi girișim sona erdiğinde çocuğun bakım ünitesine (PACU - Postanesthesia Care Unit) gönderilmeden tüm sistemlerinin kontrolü yapılmalı, cilt bütünlüğü, cilt sıcaklığı ve hidrasyon yönünden cilt turgoru değerlendirilmelidir. Çocuğun durumu gönderileceği bölüme rapor edilmelidir. Bu raporda; cerrahi süreç, çocuğun cerrahiye yanıtı, vital bulguları ve takılı olan drenler konusunda son durumu yer almalıdır. Cerrahi girişim geçiren çocukta; apne, hava yolu tıkanıklığı, aspirasyon, ekstübasyon, laringospazm, bronkospazm gibi ameliyat sonrası komplikasyonlar görülebilmektedir. Bunlar çocuğun hava yolu açıklığının tam olup olmadığının belirtisidir. Bu zaman diliminde hava yolu tıkanıkığının nedenleri; yanlış pozisyon, sekresyon birikimi, hava yolunda entübasyona bağlı oluşabilen ödemdir. Havayolu açıklığının korunması ve ventilasyona yardımcı olunabilmesi için, çocuk ayılıp kendi solunumunu yapar hale gelene kadar çocuğun hava yolunun korunması, yeterli oksijenlenmesinin sağlanması ve gerekli durumlarda sakşın uygulanması gerekmektedir (17).

Sonuç olarak çocuk cerrahisinde; çocuğun yaşı, gelişim dönemi özellikleri ve çocuk ve ebeveynin bireysel özellikleri dikkate alınarak ameliyat öncesi hazırlıklar tamamlanmalıdır. Bu sayede ameliyat olma deneyiminin hastaneye yatma sürecinden itibaren cocuklarda oluşturabileceği tüm olumsuz etkilerinin azaltılması sağlanacaktır.

\section{Kaynaklar}

1. Mooney KM. Perioperative management of the pediatric patient. Plast Surg Nurs 1997;17:69-73; quiz 74-5.

2. Işler A, Esenay $\mathrm{Fl}$, Başbakkal Z. Çocukların gelişimsel yaş dönemlerine göre tıbbi terimleri algglayışları. Türk Ped Arş 2006;41:100-106.

3. Kain ZN, Caldwell-Andrews AA, Mayes LC, Weinberg ME, Wang SM, MacLaren JE, et al. Family-centered preparation for surgery improves perioperative outcomes in children. Anesthesiology 2007;106:65-74.

4. Vatansever N. Çocuk Cerrahisi'nde Ameliyat Olan 8-12 Yaş Grubu Çocukların Hastane Ortamı ve Operasyondan Etkilenme Durumlarının Belirlenmesi (Yüksek Lisans Tezi). Istanbul: Marmara Üniversitesi; 2008.

5. LeRoy S, Elixson EM, O'Brien P, Tong E, Turpin S, Uzark K; American heart association pediatric nursing subcommittee of the council on cardiovascular nursing; council on cardiovascular diseases of the young. Recommendations for preparing children and adolescents for invasive cardiac procedures. Circulation. 2003;108:2550-64.

6. Sadhasivam S, Cohen LL, Szabova A, Varughese A, Kurth $C D$, Willging $P$, et al. Real-time assessment of perioperative behaviors and prediction of perioperative outcomes. Anesth Analg 2009;108:822-6.

7. Alak V. Hastaneye ameliyat olmak üzere gelen 7-14 yaş grubu çocukların korkuları ve hemşirelik uygulamaları (Doktora Tezi). Izmir: Ege Üniversitesi; 1993.

8. Chorney JM, Kain ZN. Family-centered pediatric perioperative care. Anesthesiology 2010;112:751-5.

9. Altay NC. Çocuklarda Ameliyat Öncesi Hazırlık. Sağlık Bilimleri Fakültesi Hemşirelik Dergisi 2008;68-26.

10. McGraw T. Preparing children for the operaating room: phsychological issues. Can J Anaesth 1994;41:1094-103.

11. Lindeman CA, Stetzer SI. Effect of preoperative visits by operating room nurses. Nurs Res 1973;22:4-16.

12. Justus R, Wyles D, Wilson J, Rode D, Walther V, Lim-Sulit N. Preparing children and families for surgery: mount sinai's multidisciplinary perspective. Pediatr Nurs 2006;32:35-43.

13. Wright KD, Stewart SH, Finley GA, Buffett-Jerrott SE. Prevention and intervention strategies to alleviate preoperative anxiety in children. Behav Modif 2007;31:52-79.

14. Semerci ZB. Bilinmezin kapısındaki çocuk ve aile: çocukların ve ailelerin cerrahi işlemlere hazırlanması. Hacettepe Tıp Dergisi 1999;30:226-8.

15. Mahmoudi-gharaei J, Moharari F, Shahrivar Z, Ashjaei B, Alirezaei N, Parizad J. Effect of preoperative play interventions on post surgery anxiety. Iran J Psychiatry 2008;3:20-4.

16. Alikaşifoğlu M. Adölesana Yaklaşım. Türk Ped Arş 2005;40:191-8. 
17. Leack KM. Perioperative management of the child. In: Wise BV, McKenna C, Garvin G, Harmon BJ (eds). Nursing Care of The General Pediatric Surgical Patient. USA: Aspen Publisher 2000; p.16-23.

18. Lui JCZ, Wu KK. Parental anxiety associated with participation in anaesthetic induction in children: questionnaire survey. Hong Kong Med J 1999;5:21-6.

19. Karabulut N, Arıkan D. The Effect of differen training programs applied prior to surgical operation on anxiety levels. New Symposium Journal 2009;47:64-9.

20. Chorney JM, Kain ZN. Behavioral analysis of children's response to induce of anesthesia. Anesth Analg 2009;109:1434-40.
21. Cartwright CC, Wallace DC, (eds). Nursing Care of the Pediatric Neurosurgery Patient. Germany: Springer-Verlag Berlin Heidelberg; 2007.

22. Gauderer MW, Lorig JL, Eastwood DW. Is there a place for parents in the operating room? J J Pediatr Surg 1989;24:705$6 ; 707$.

23. Kirby C. Paediatric surgery. In Whalan C ed. (2006) Assisting at surgical operations. A practical guide. New York: Cambridge Press 2006; p.145-149.

24. Wilson CM. Perioperative fluids in children. Update in Anaesthesia 2005;19:1-3. 